\title{
Post-occupancy Evaluation with Emphasis on Thermal Comfort: A Case Study in Public Squares
}

\author{
Carlos A. C. Niemeyer ${ }^{1}$ and Lucila C. Labaki ${ }^{2}$ \\ 1. Federal Institute of Education, Science and Technology, Sao Paulo 01109-010, Brazil \\ 2. Scholl of Civil Engineering and Architecture of Campinas University, Campinas 13083-889, São Paulo, Brazil
}

\begin{abstract}
The article presents a case study about thermal comfort in two public squares located in the coastal region of southeastern Brazil, within a post-occupational assessment context where it was sought to estimate the thermal sensation and perception of the users generating systematized knowledge about the built environment. The objective is to instruct future interventions for improvement in the living condition where it is particularly important for the success of the activities predicted there. Surveys on thermal comfort along with goers of the squares were held on three consecutive days in April 2013 and February 2014 with microclimate monitoring of the places adopting the predictive PET (physiological equivalent temperature) index calculated based on the bioclimatic model Rayman. The obtained data set generated valuable information about the pattern of thermal comfort allowing understanding the analytical correlations between PET index, climate variables and the perception of comfort. The article seeks to contribute towards the recognition of bioclimatic specificities in the project process aimed to the improvement of the environmental and social performance of public squares and aspects that are relevant to the urban planners.
\end{abstract}

Key words: Post-occupancy evaluation, public spaces, thermal comfort.

\section{Introduction}

The increasing concentration of population in urban areas expanded the contemporary interest in ensuring better quality to the public space appropriation within a sustainability environmental and social perspective [1-3].

The social spaces, considered as "locus" of the experience, acquire a value estimation when under certain sensory and perceptive circumstances assume a specificity that makes what Tuan [4] called "place": an attractive environment of perception, reading and apprehension. It still implies an important and underlying comprehension that retrieves the recognition of the climate influence in the project process to which we call bioclimatic architecture, seeking to understand and articulate the embracing to the designs of human comfort [5-8].

Corresponding author: Carlos A. C. Niemeyer, Ph.D., professor, research fields: post-occupancy evaluation, public spaces and thermal comfort. E-mail: carlosniemeyer@ifsp.edu.br.
The environmental issue was already a reason of concern in the treatises of antiquity to which we drink from this source. The location of squares and road complexes in Hellenism was associated with favorable positions to the wind and the light [9]; The introduction of trees to provide shadow surroundings near the fountains for irrigation and cooling of the air was a necessity to Mesopotamian people in search for better environmental conditions [10]. Thus the importance of bioclimatic performance emerges as a parameter of support of an urban environmental infrastructure which intends to conciliate environmental and social purposes.

The "square", object of this study, is the place of permanence and meeting morphological element of the city that is distinguished from residual spaces by having a spatial organization and an intentionality projectual [11]. The image of the public place refers by excellence, which states and establishes the urban phenomenon influencing our identity, our sense of security and interaction with people $[12,13]$. The 
success or failure of an open public space is related to the ability to predict and adapt external variables (physical, cultural and environmental) to the social expectations aggregating what Scudo and Dessi [14] call as "multi-sensorial" performances focused on the imperatives of habitability.

The international standard ANSI/ASHRAE [15] defined "thermal comfort" as a "condition of mind that expresses satisfaction with the thermal environment" and specified the acceptable thermal conditions for human living environments. Thermal comfort studies show a variation between environmental (temperature and relative humidity of the air, wind speed and radiation) and personal variables (metabolism and clothing isolation rate) in the perceived evaluation of comfort quantified through predictive indexes: commonly-used PET (physiological equivalent temperature) models by Hoppe [16]; PMV (predicted mean vote) by Fanger [17]; SET (standard effective temperature) by Gagge et al. [18]; UTCI (universal thermal climate index) by Fiala et al. [19]. Those studies were very well documented with features and performance limitations in different thermal requests [20-22].

Additional studies in thermal comfort suggest the existence of adaptive psychological motivation factors responsible for self-adjustment of the human organism to external thermal condition, assuming an active emotional component on the control of environmental stimulation with sensitive implications for the allocation of an urban design [7, 23-25].

Field investigations conducted in Greece by Nikolopoulou and Likoudis [26] have shown differences of up to $44 \%$ of the sample feeling comfortable in the ASV (actual sensation votes) in comparison to the measures by PMV index which suggests the tendency to relativize purely objective assessments on cognitive influences that act in the person-environment relation. Study conducted by Knez et al. [27] in two urban parks located in Tokyo (Japan) and Goteborg (Sweden) reiterates distinct reported perceptions of thermal among the users, confirming the presence of a cultural component intervening in the subjective evaluation of comfort, which demonstrates that design elements can promote a better adaptation person-environment accommodating fluctuations in levels of thermal discomfort.

The urban climate is strongly influenced by the characteristics of the built environment as the geometry of buildings, types of materials, anthropogenic heat surfaces, presence of vegetation and extensions of water, generating variations in the microclimate that interfere in the human thermal balance and, consequently, in the conditions of comfort $[6,8]$. Case studies on several methodologies have investigated active bioclimatic performances in open spaces design in different urban areas pointing guidelines for improvement of thermal environment, based on the utilization of predictive indexes of comfort. Some researches adopted the predictive method of PET in the analysis of the thermal environment conducted in the cities of Lisbon [28, 29], Chennai (India) [30], Szeged (Hungary) [31], Hong Kong [32], Taiwan [33], Freiburg [34] and in several Brazilian cities [35-37].

The PET index, developed by Mayer and Höppe [38] based on the MEMI (model of human energy balance of Munich), is the product of a fictitious logic that evaluates the human thermal complex in standardized environment, being an index suitable for measurement of thermal conditions in internal and external environments [22, 39, 40]. This predictive index of comfort is particularly suited to the interests of the urban planners by using accessible climate data as humidity, air temperature, globe temperature and air speed, data that allow generating the mean radiant temperature $\left(T_{m r}\right)$, important bioclimatic parameter of temperature evaluation of the surrounding environment used in the PET calculation. The PET index has been widespread along with the computational model RayMan-1.2, developed by the 
Meteorological Institute of Freiburg [41] and used in surveys of urban comfort.

The objective of this study is to evaluate the pattern of thermal comfort in two public squares situated in a small coastal town in Brazilian Southeastern, adopting the PET index and having its results correlated to subjective assessments raised through field surveys. The purpose lies in understanding the active condition in the thermal environment and the generation of an informational scope to allow subsidizing post-occupational interventions in order to adjust the active microclimate parameters to the required conditions.

Such adjustment means to propose environments more comfortable or neutral, that is, with few thermal constraints where people can feel environmentally encouraged to enjoy the places with satisfaction and well-being. Whereas the focus of landscape architecture is to sort the space in relation to the human, we understand that the space must comprise a multidisciplinary approach (landscape design + ergonomics + environmental comfort) in order to conceive environments that respond to the needs, limitations and motivations of the users. The thermal comfort thus becomes a component of good planning adapting urban spaces to required usability.

\section{Materials and Methods}

\subsection{Area of Research and Description of the Analysis Units}

The northern coast of São Paulo, located in the southeastern region of Brazil (Fig. 1), is characterized by a rainy tropical climate according to Köppen-Geiger climate classification, with no dry season, a humidity rates generally above $80 \%$ and an average annual temperature above $25{ }^{\circ} \mathrm{C}$. Large part of the county is taken by the exuberant Atlantic rainforest, responsible for the high local cloudiness making the insolation diffuse by reflecting great part of the direct radiation of short-wave. Preventing the dissipation of heat retained on surfaces causes stuffiness and the sensation of thermal discomfort that occurs, especially at night.

The units of analysis are located in the central area of the city, 200-m distant from each other. The first, Cândido Mota Square (Fig. 2), is a square predominantly paved with about $6,000 \mathrm{~m}^{2}$ located in the heart of the city, and that adds strong empathy and popular appropriation. The enclosure, partially closed on two sides, has a passive function serving as the city's lounge with its long concrete seats, high thermal conductivity materials $(\lambda=1.75 \mathrm{~W} / \mathrm{mK})$, contouring flower beds and a base in Portuguese mosaic $(\lambda=1.60 \sim 2.90 \mathrm{~W} / \mathrm{mK})$ shaded with large trees.

The second, Diógenes Ribeiro Square (Fig. 3), called "square of the beach", has about 9,000- $\mathrm{m}^{2}$ area connected in its smaller dimension to a busy side boardwalk. Its design resembles a public garden of eclectic taste with winding paths defining broad lawns and abundant trees that make it gloomy in some spots. The base is incorporated from concrete and mortar $(\lambda=1.15 \mathrm{~W} / \mathrm{mK})$ with benches in wood and concrete considered uncomfortable. It contains fitness equipment, living environments and playground, however, it is a little frequented square, but on the weekends, it becomes lively because of a traditional handicraft fair and popular amenities.

\subsection{Materials}

For the monitoring of environmental variables (air temperature, globe temperature, relative humidity and wind speed), it was used fixed registers (Figs. 4 and 5), developed by the Laboratory of Environmental Comfort and Applied Physics of FEC, Uni.camp., with sensors attached at a height of $1.10 \mathrm{~m}$ as recommended by ISO7726/98, consisting temperature gauges and humidity-175-HI e 175-T2 models - Brand Testo with records of 15/15 min. For wind speed measurements, it was used a hot wire manual anemometer - 405-V1 model, Brand Testo, with measures taken at $2.00 \mathrm{~m}$ of height every $15 / 15 \mathrm{~min}$. A digital camera, EOS-450D with lens-eye fish model 
EX-4.5-mm was used to record the SVF (sky view factor).

\subsection{Methods}

The research proposes a descriptive and longitudinal approach correlating microclimatic parameters (air temperature and wet bulb, air speed and relative humidity of the air) measured by devices with thermal sensations reported to determine the active thermal comfort conditions. The approach was performed in two stages with measurements made on three consecutive days in April 2013 and February 2014 during the day (from 8 a.m. to 6 p.m.), parallel to surveys with the goers of the squares totaling

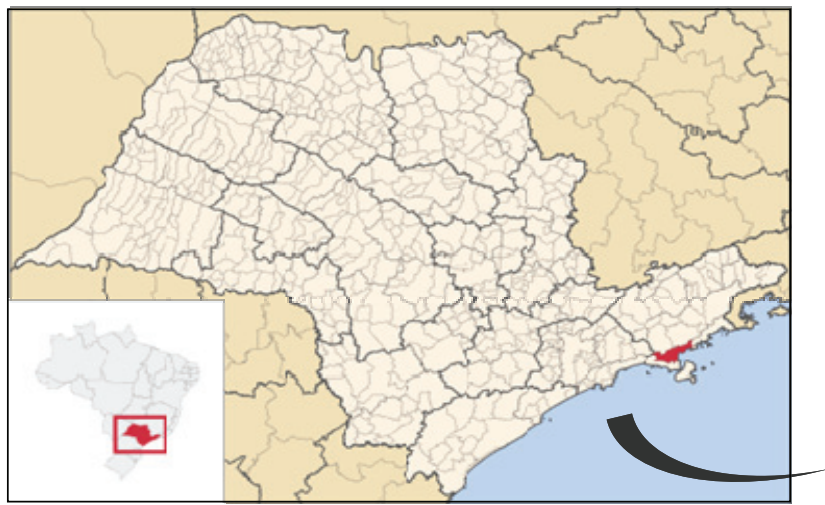

Fig. 1 Geographical localization.

Source: IBGE (Instituto Brasileiro de Geografia e Estatística).
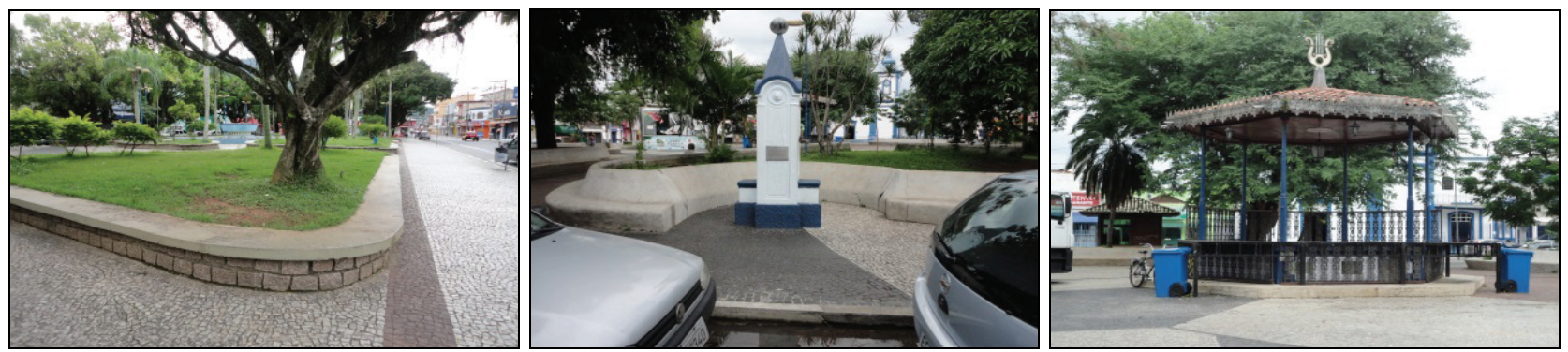

Fig. 2 Cândido Mota Square.
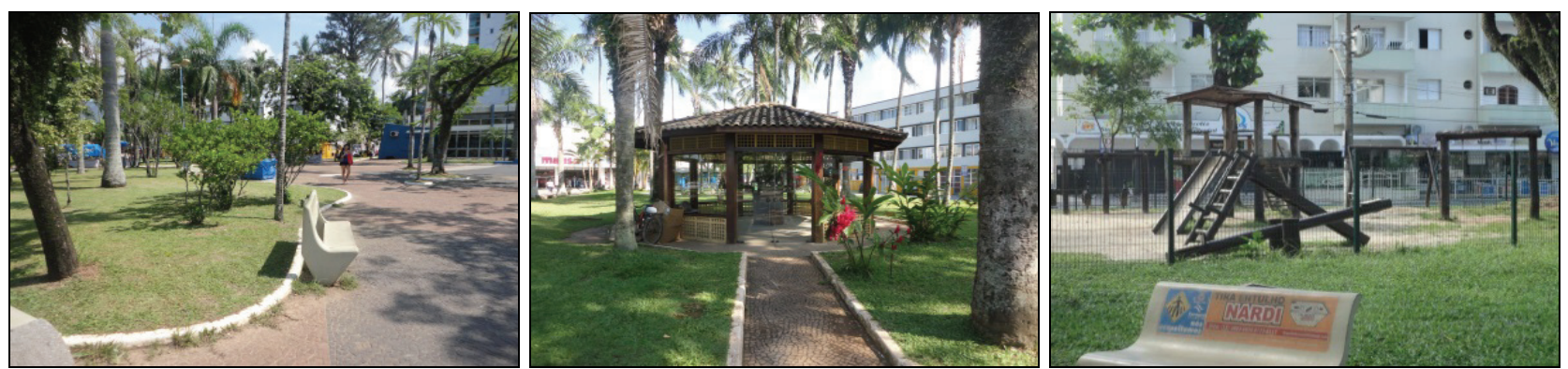

262 interviews conducted by two interviewers teams. Semi-structured questionnaires were applied for raising social and thermal sensation data based on the European method RUROS (Rediscovering the Urban Realm and Open Spaces). A platform developed for the analysis of open spaces combining the physical environment with usage requirements and satisfaction, described by Nikolopoulou and Lykoudis [24]. RUROS uses a five-point scale ranging from "very cold" (-2) to "too hot" $(+2)$, defined as ASV, passing through the neutral range to the center, called "comfortable" in order to reiterate such condition to the respondent. And the degree of thermal perception, also on a five-point scale, ranging from "much colder"

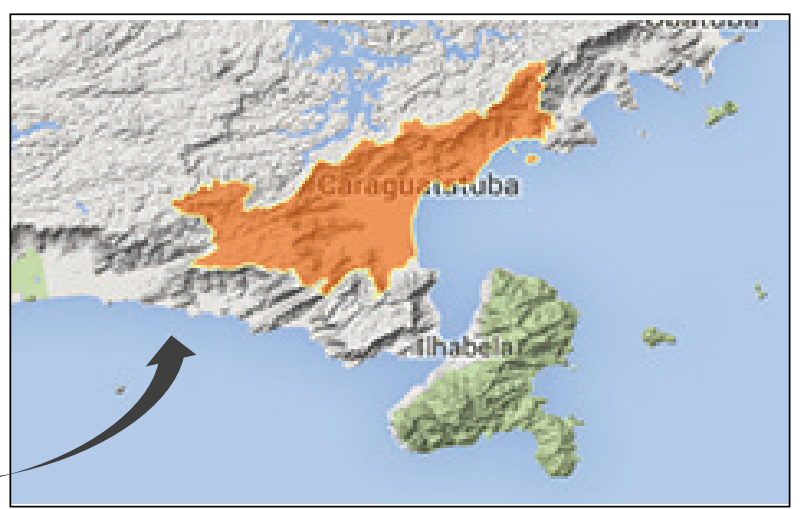

Fig. 3 Diógenes Ribeiro Square. 
to "much heat" (over heat) passing through the intermediate scale located in the center, is named as "equal". Weather conditions were raised (air temperature, relative humidity, air velocity and radiation index) and provided by the local weather station for causal correlations between the thermal environment and human comfort.

Statistical procedures were performed seeking correlations with the interpretative range of comfort for PET, considered here $18^{\circ} \mathrm{C}$ to $26^{\circ} \mathrm{C}$ according proposed calibration to the city of São Paulo (Brazil) by Monteiro and Alucci [42]. In this work, PET was generated through the computational model Rayman, established in Matzarakis and Amelung [40], introducing term physiological parameters as thermal resistance of vesture and physical activity and the input variables: geographic coordinates, relative humidity, air temperature, air velocity and the mean temperature radiant $\left(T_{m r}\right)$. The latter was based on Eq. (1) disposed in ISO7726/98 [43] and presented below:

$$
T_{m r}=\left[\left(t_{g}+273\right)^{4}+\frac{1 \times 1.10^{8} \cdot v_{a}^{0.6}}{\varepsilon_{g} \cdot D^{0.4}} \cdot\left|t_{g}-t_{a}\right|^{1 / 4} \cdot\left(t_{g}-t_{a}\right)\right]^{1 / 4}-273
$$

where:

$D=$ diameter of the globe (standard model $D=0.15 \mathrm{~m})$;

$v_{a}=$ air velocity level to the globe $(\mathrm{m} / \mathrm{s}) ;$ $\varepsilon_{g}=$ emissivity of the black globe (0.95);

$t_{g}=$ globe temperature;

$t_{a}=$ air temperature.

The soft Rayman adopts the $T_{m r}$ as human energy balance model to evaluate the urban bioclimate through thermal indices as PMV, SET and PET used here. Yet, hemispheric images were taken for calculation of the SVF, important parameter of estimation of radiation flows in complex environments. The shots were made at $1.00 \mathrm{~m}$ high from the floor and subsequently generated (Table 1) through the Rayman model. The SVF expresses morphological factors of the study area into a single value allowing relevant climate information.

\section{Results and Discussion: Microclimate Assessment}

The use of open spaces is closely linked to efficiency in obtaining means that allow balancing the body heat gains and mitigating the thermal discomfort that occurs in highly processed places under direct and indirect action of solar radiation. In order to assess the extent of these active thermal components, microclimate and meteorological surveys were carried out, whose correlations found between parameters analyzed allowed the thermal environment in-situ understanding and illuminated appropriate strategies for the improvement of the habitability.

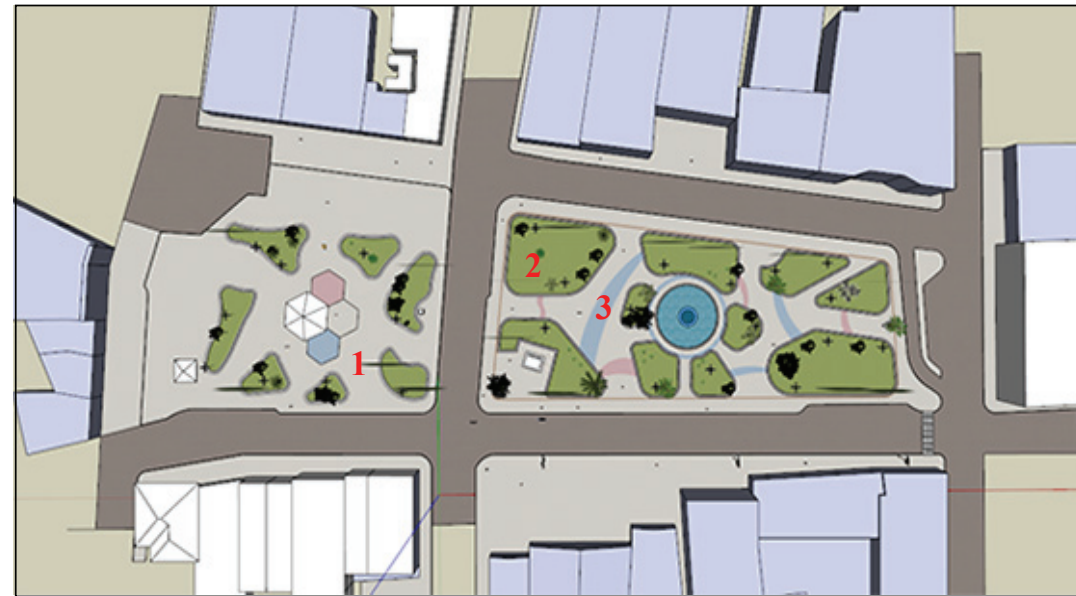

(a)

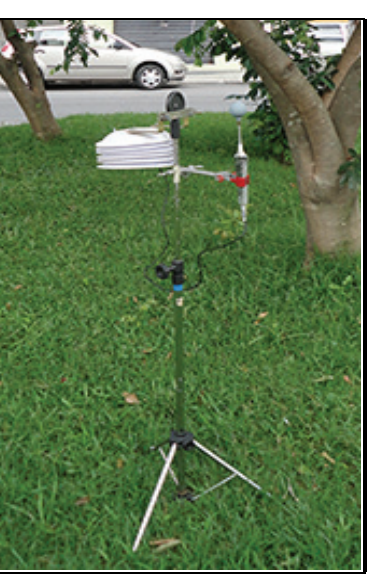

(b)

Fig. 4 Cândido Mota Square: (a) design (map) with the measuring points (1 2): the 3rd hemispheric photo at the center; (b) an image of the fixed recorder of temperature and humidity in the detail. 


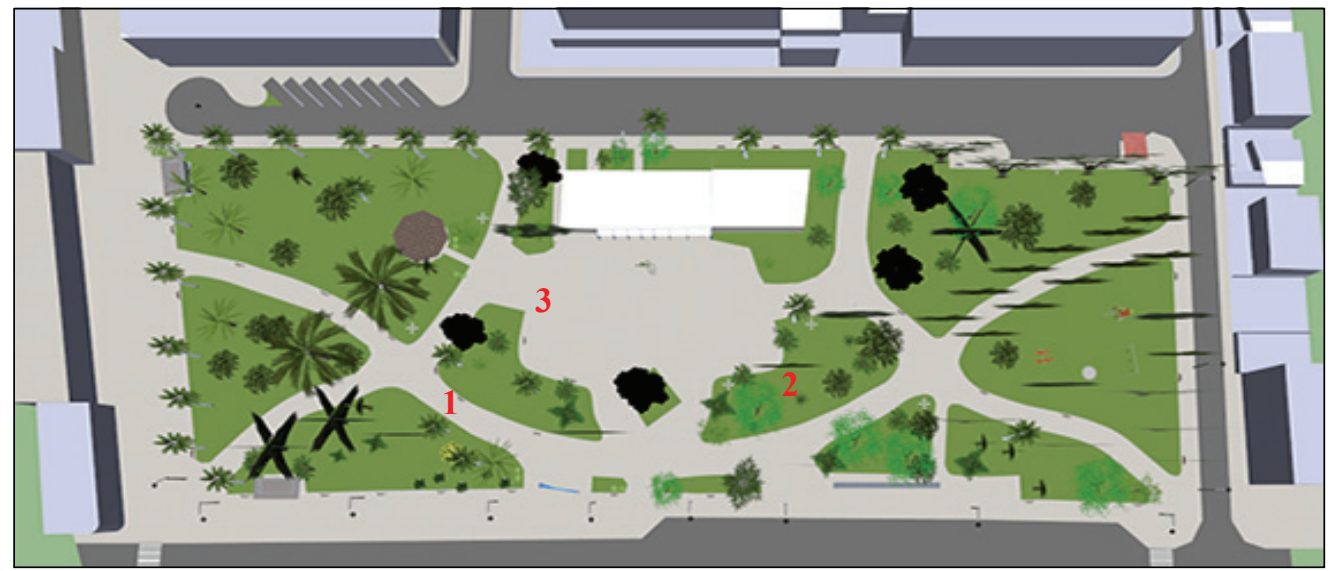

Fig. 5 Diógenes Ribeiro Square with the measuring points (1-2) and the 3rd hemispheric photo at the center.

Comparing the measured variables with the weather station situated on the outskirts of the city, it was permitted to confirm sensible changes to the urban climate due to the strong thermal exchange between paved surfaces causing the temperature increase (rise) in the central area of the city. The Cândido Mota Square ("A") reached temperature variations of up to $3.4{ }^{\circ} \mathrm{C}$ for the autumnal month (April 2013). In the same period the Diógenes Ribeiro Square ("B") reached nearly identical variations reaching up $3.3{ }^{\circ} \mathrm{C}$ of difference. On summer days, such difference has stressed to $4.1^{\circ} \mathrm{C}$ in the Square "A" and $4.3{ }^{\circ} \mathrm{C}$ in the Square "B", a slight advantage to the first thermal cooling, which qualifies the hypothesis of the occurrence of a differentiated urban climate.

Several studies in large and small urban areas have reported similar differences of center-periphery temperature suggesting that these disorders point to the occurrence of the phenomenon of the called "HI (heat island)" [31, 44-46]. Giridharan et al. [44] found variations in the range of up to $3.4{ }^{\circ} \mathrm{C}$ in the coastal region of Hong Kong revealing localized differences due to influences of albedo, altitude (height), presence of vegetation, sea proximity and urban geometry. Gulyas et al. [31] also confirmed occurrence of HI in Szeged (Hungary), a city of 160,000 inhabitants with an average annual intensity of up to $6.8^{\circ} \mathrm{C}$. In contrast, mitigating alternative of the HI's phenomenon has been successfully reported with the massive and attenuator use of vegetable component [47-50].
High local temperatures are related to high gains (earnings) and heat emissions from urban pavements, having a causal relation with the insolation [51,52] evaluated by the SVF. The SVF has a low correlation with the air temperature (microclimate), but strong correlation with the surface temperature and consequently with the phenomenon of HI's, allowing identifying places with high insolation features and a consequent low appropriation [53, 54] (Table 1).

During the first monitoring period in April 2013, the correlation between ASV, thermal preference and PET in the Square "A" enabled the checking of a balance in the comfort with a significant percentage of users reporting a thermally "comfortable" state considering here the neutral temperature in the range of $18{ }^{\circ} \mathrm{C}$ to $26{ }^{\circ} \mathrm{C}$. The thermal preference reported reiterates the state of comfort previously reported for a wide range of users (74.4\%), as shown in Fig. 6. The Square "B" introduced identical performance with users reporting a comfortable thermal sensation for a PET set in the same range of neutrality by bringing a mostly comfortable environment for both squares in the autumnal season (Fig. 6). In the second monitoring period in February 2014 (Fig. 7), coinciding with high summer in Brazil, the Square "A" indicated an ASV in thermal neutrality status for a PET indicating the contrary, a high thermal stress on light levels $(+1)$ to high (+2).

The thermal preference also reiterated the state of 
neutrality pointed out in the ASV but with a tendency to milder temperatures $(-1 /-2)$. The Square "B" accused a state of thermal neutrality less vigorous with significant preference of users also tending to milder temperatures. PET has remained high on the hottest tracks $(+1 /+2)$ in opposition to the ASV revealing the important role of cognition acting on environmental stimulation and the consequent physiological adaptation phenomenon, already well documented by Nikolopoulou and Stemmers [7]. The adaptation to high temperature is associated with the culture of leisure outdoors in Brazil for all seasons of the year contributing to greater adaptation to the rigors of the climate.

Table 1 Hemispheric images of three SVF (sky view factor) monitoring points.

\begin{tabular}{|l|l|l|l|}
\hline Cândido Mota Square & Point $2 \mid \mathrm{SVF}=0.058$ & Point 3 SVF $=0.535$ \\
\hline Point $1 \mid \mathrm{SVF}=0.262$ & & & \\
\hline & & & \\
\hline
\end{tabular}

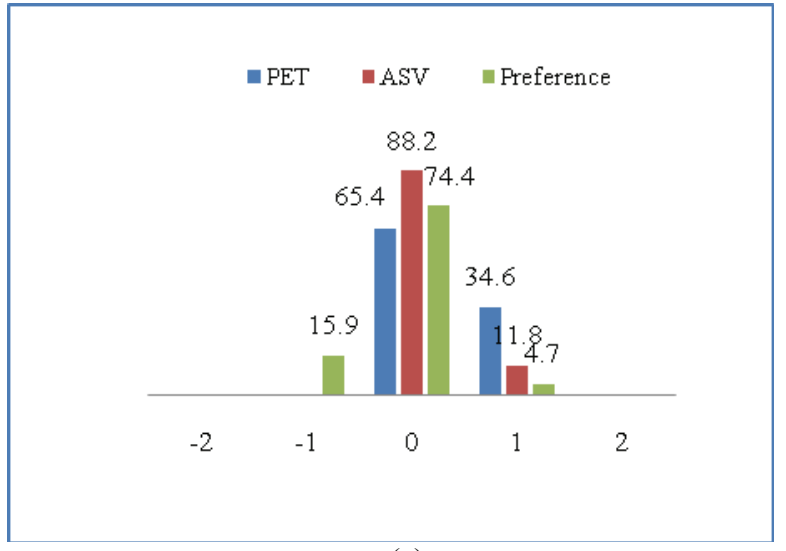

(a)

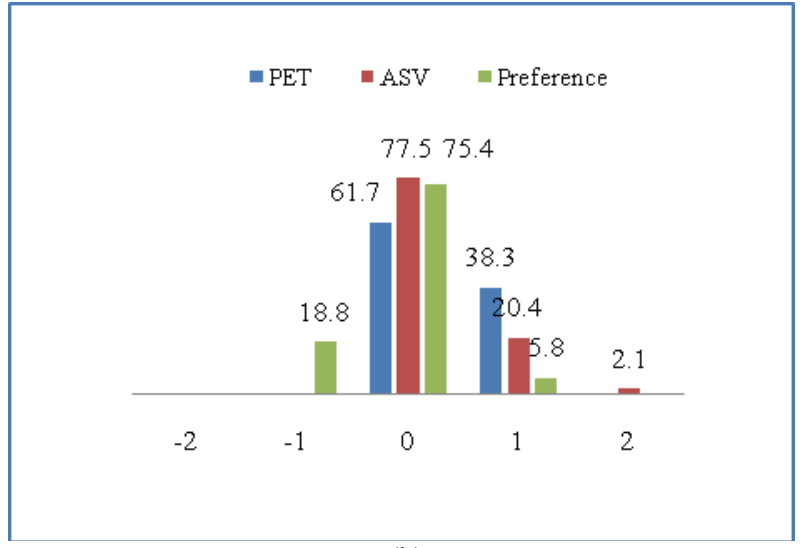

(b)

Fig. 6 Correlations between PET $\times$ ASV $\times$ thermal preference (autumn 2013): (a) Candido Mota Square; (b) Diogenes Ribeiro Square. 


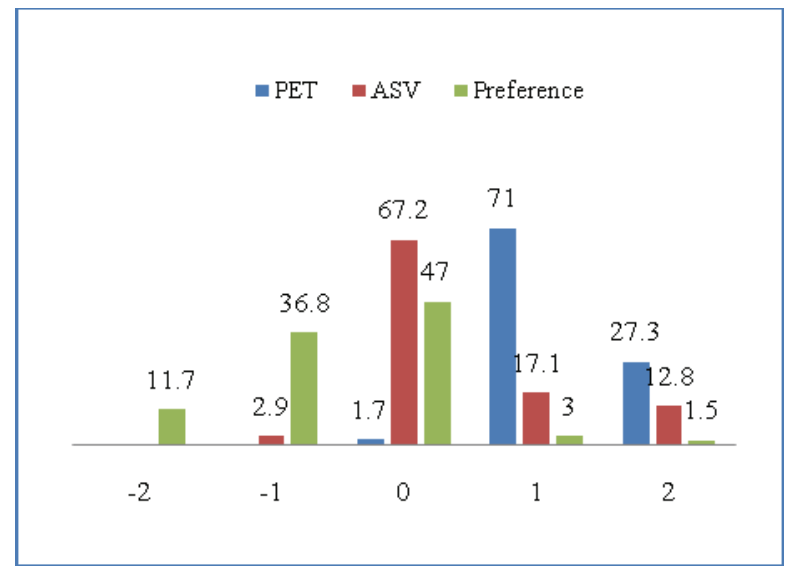

(a)

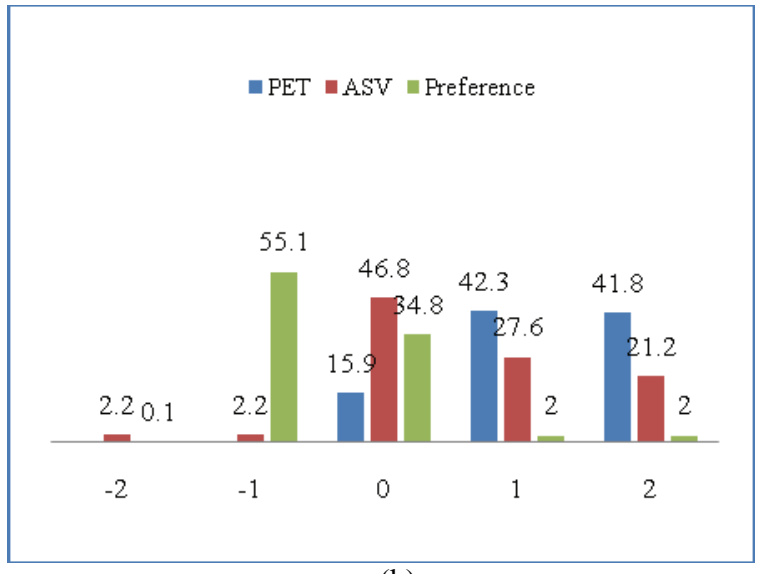

(b)

Fig. 7 Correlations between PET $\times$ ASV $\times$ thermal preference (summer 2014): (a) Candido Mota Square; (b) Diogenes Ribeiro Square.

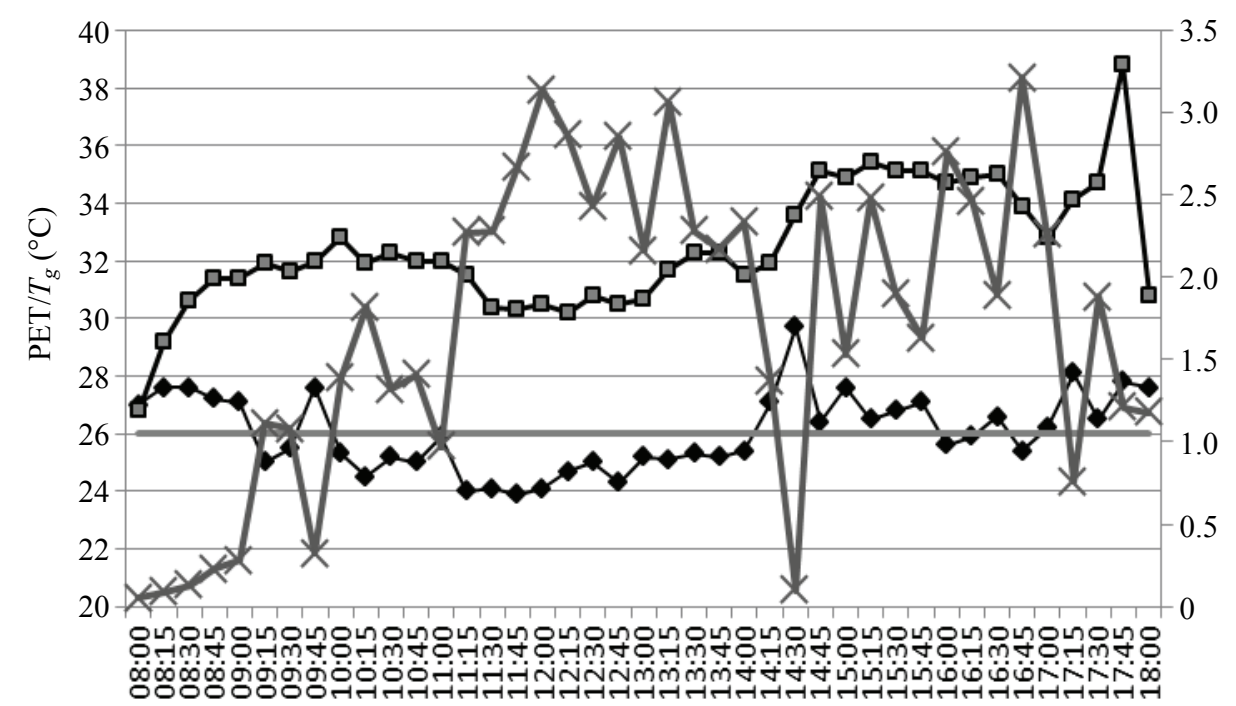

(a)

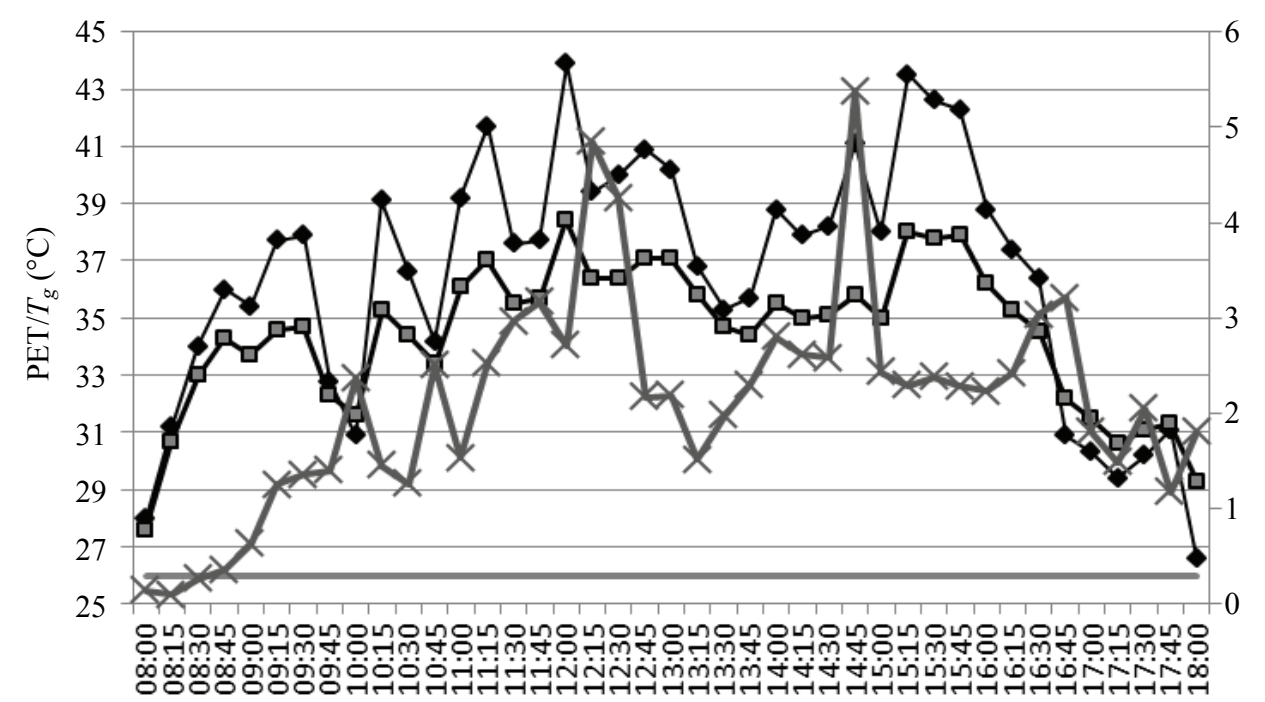

(b)

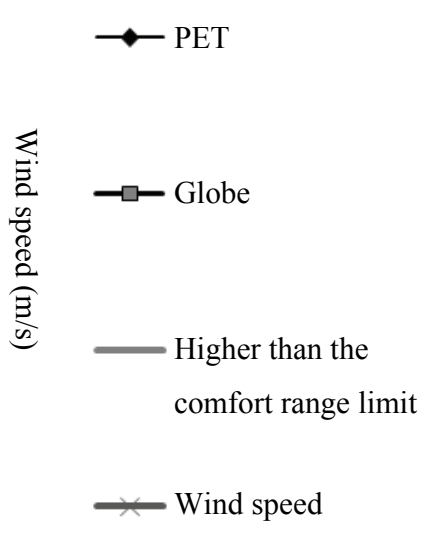

Fig. 8 Thermal performance of Diógenes Ribeiro Square: (a) Point 1 on February 7, 2014; (b) Point 1 on February 9, 2014. 


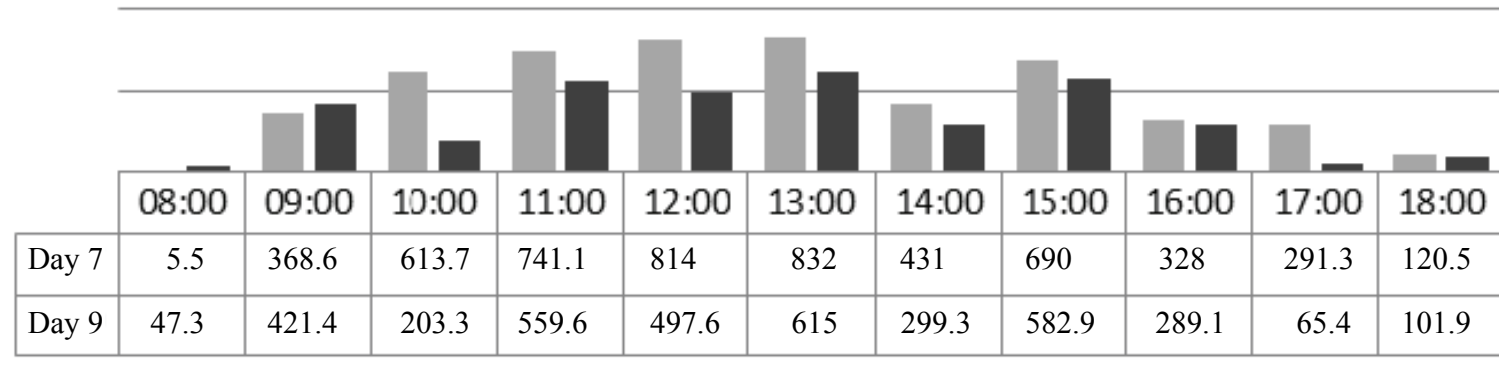

Day 7

Day 9

Fig. 9 Index of solar radiation $\left(\mathrm{w} / \mathrm{m}^{2}\right)$ measured at the weather station site. Source: Cepagri-Uni.camp.

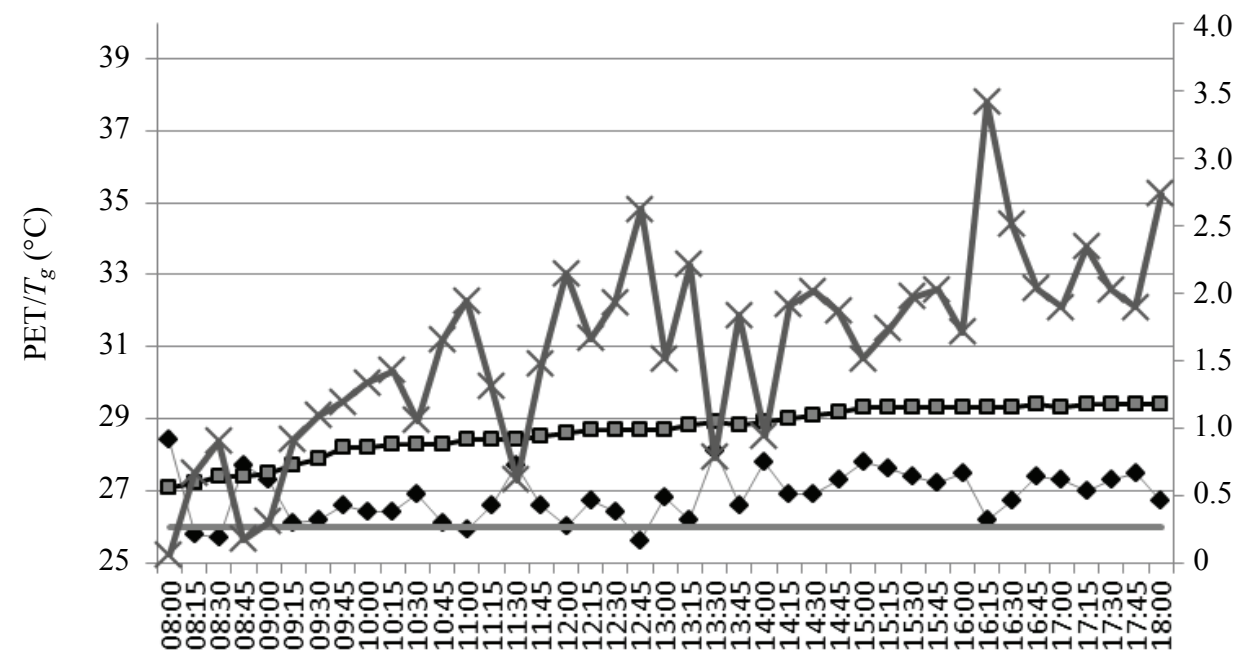

(a)

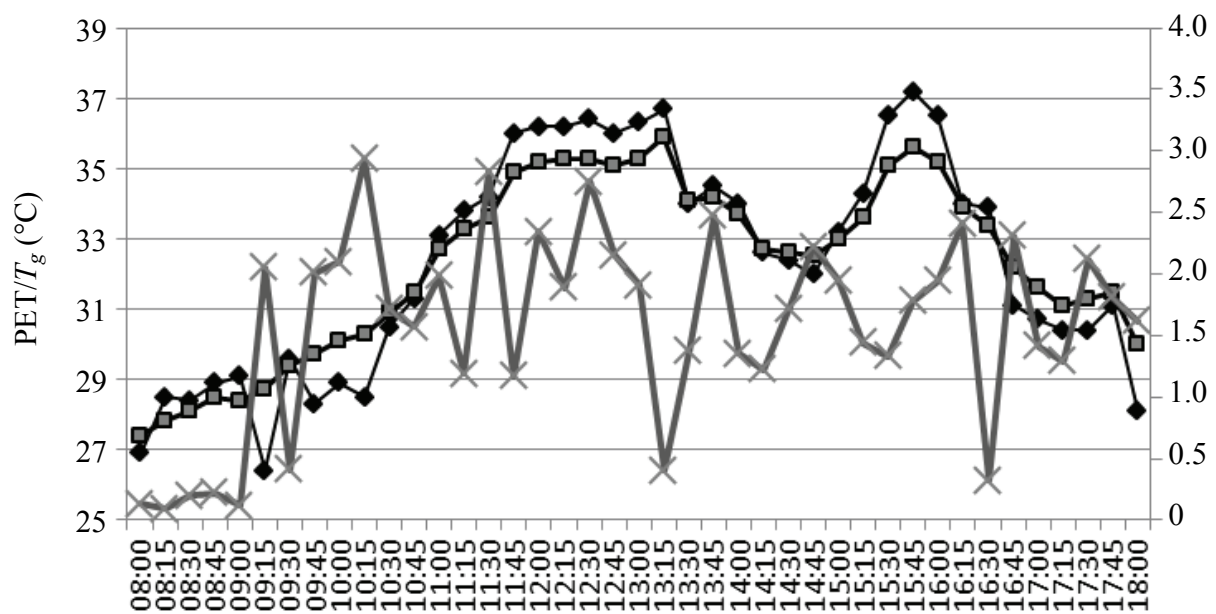

(b)

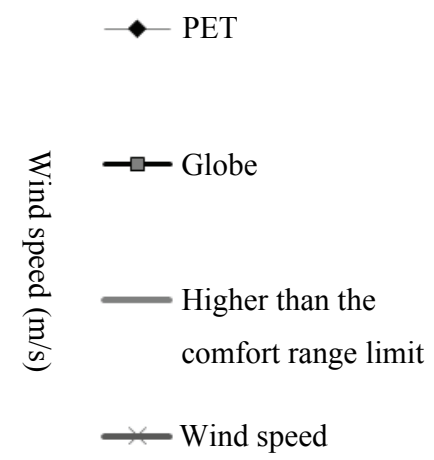

$\rightarrow$ PET

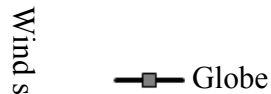

Higher than the comfort range limit Wind speed

Fig. 10 Thermal performance of Cândido Mota Square: (a) Point 1 on February 7, 2014; (b) Point 1 on February 9, 2014. 
Analyzing the variables measured in February 7 and 9, 2014, hot days of summer, it is verified a strong negative correlation between PET and air velocity confirming the wind coolant value in the balance of body heat when tensioned by high (elevated) temperature emitted from the surfaces of high thermal capacity of the surrounding. The wind acceleration for values above $2 \mathrm{~m} / \mathrm{s}$ occurred on February 9 between 10:45 a.m. and 2:00 p.m. sharply dropped the PET restoring the comfort temperature at the Diógenes Ribeiro Square and a little less in the Cândido Mota Square due to the turbulence caused by the roughness of the built environment in that place (Figs. 8-10).

In high radiation conditions, like those found on February 7 (Fig. 9) characterized by low relative humidity and a clear sky, it was produced a sharp rise of the air temperature and of the radiant heat affecting the $T_{m r}$, important factor of PET qualifier. This does not occur on Day 9 due to increase wind speed, restoring the temperature to near the comfort zone on both squares alleviating the effects of increased humidity that day. The analysis shows that the favoring of the air movement, the radiant temperature control and the reduction in absorption of solar radiation are sensitive parameters that imply the improvement of comfort conditions in an extremely hot and humid region as found in the southeastern Brazilian coast.

\section{General Recommendations for Improvement of Thermal Comfort in the Context of POE (Post-occupancy Evaluation)}

From the collected results, the study suggests recommendations in the context of a hypothetical post-occupational intervention necessary to impose targets for improvements in thermal environment from the conducted observations and the PET and ASV indicators. In the context here proposed, constructive improvements are targeted in a perspective of short, medium or long term based on raised diagnostics.
POE seeks to recover performance standards that ensure social satisfaction with the aesthetic functional and environmental quality, serving as a quality control mechanism of the built environment $[55,56]$. It allows generating systematic knowledge about the relational aspects person-environment, allowing a greater adaptability of the final product to its user ensuring social and environmental sustainability.

In a moment which exacerbates social atomization around private consumption centers, we should invest even more in diversified landscaped public areas, equipped and preserved in order to comply with criteria of performance and efficiency offering convenience, comfort and enjoyment. Even if the abandonment of the public square among the wealthiest layers of the population is a reality in many places, this phenomenon does not find the same intensity among the popular layers, whose communities are quite resilient to the omission of public authorities, with regard to the maintenance of these spaces, seeking to adapt different forms of use of open areas even in adverse physical conditions.

Having as focus on the evaluation of thermal performance of enclosures, some general recommendations, aimed at improvements in the standard of comfort in climate requests of hot and humid type, suggest make the most of the effect of cooling ventilation associated to the resources of natural shading. Improvements in physical indicators can be obtained with the replacement of high thermal capacity pavements reducing the absorption and the transmission of radiation attenuating the thermal exchanges and can be summarized here in the following recommendations:

- low thermal capacity of the material surfaces;

- absorptivity coefficient by the color $<0.6$;

- light colors (average albedo);

- promote strengthening of the arboreal vegetable component in order to mitigate the direct incidence of solar radiation of short and long waves in high SVF places. Give preference to vegetables sets that belong 
to the floristic mosaic of the local ecosystem;

- reconcile natural shade with plant floors in order to absorb the solar radiation;

- avoid constructive barriers to the direction of the prevailing winds. Choose for plant masses with visual permeability around $50 \%$;

- opt for permeable pavements, interlocked cement and exceptionally light colored stones (other except white).

\section{Conclusions}

As a conclusion, we suggest the optimization of landscape planning focusing on performance compared to the compensatory mechanisms of the human thermal comfort and on the analysis of the phenomena that impact the built environment. The diagnosis of thermal performance illustrated here thus allows determining decision-making based on physical-climatic conditions observed.

The emphasis should be directed to the design process with the landscape design if buildings are based on new paradigms guided by the technological incorporation as establishment of simplified models of simulation and prediction of the thermal environment using meteorological data evaluation and reported information of sensation and thermal perception. And so, conceive projective answers that accommodate microclimate settings appropriated to the particularities of each region and the environmental needs of the user.

The survey results thus point to the need to reinforce environmental policies focused on knowledge of the active conditions in the climate envelope of the place and conceive an environmental infrastructure that, in the hot and humid tropics, ventilation paths provide in an urban structure with low roughness having low template in edge. We believe that the proposal should be inserted to a larger context of a cooling urban network focused on mitigation of thermal discomfort strongly based on arboreal component cooling the impact of the HI responsible for the urban climate change. Favoring to the natural processes (environmental design), the review of the constructive processes with use of low thermal capacity materials tends to decrease the pressure of radiant heat creating conditions to restore the environmental comfort and the improvement of the habitability in our public spaces.

\section{References}

[1] Corraliza, J., and Aragones, S. I. 1993. "Social Psychology and the Urban Fact." Supplement 5: 411-26. (in Spanish)

[2] Corraliza, J. 2000. "Urban Life and Social Exclusion." Intervencion Psicosocial 9 (2): 169-83. (in Spanish)

[3] Jacobs, J. 1961. The Death and Life of Great American Cities. New York: Random House and Vintage Books.

[4] Tuan, Y. F. 1977. Space and Place: The Perspective of Experience. Minneapolis (MA): University of Minnesota Press.

[5] Eliasson, I. 2000. "The Use of Climate Knowledge in Urban Planning." Elsevier: Landscape and Urban Planning 48: 31-44.

[6] Givoni, B. 1998. Climate Considerations in Building and Urban Design. New York: John Wiley \& Sons, Inc.

[7] Nikolopoulou, M., and Steemers, K. 2003. "Thermal Comfort and Psychological Adaptation as Guide for Design Urban Spaces." Elsevier: Energy and Buildings 35: $95-101$

[8] Olgyay, V. 2010. Architecture and Climate. Barcelona: Gili. (in Spanish)

[9] Sitte, C. A. 1992. Construction of Cities According to Their Artistic Principles. São Paulo: Ática. (in Portuguese)

[10] Laurie, M. 1983. Introduction to the Architecture of the Landscape. Barcelona: Gili. (in Spanish)

[11] Lamas, J. 2006. Urban Morphology and City Design. Lisbon: Fundação Calouste Gulbenkian. (in Portuguese)

[12] Cullen, G. 1971. Townscape. New York: Architectural Press.

[13] Lynch, K. 1960. The Image of City. Cambridge: MIT Press.

[14] Scudo, G., and Dessi, V. 2006. "Thermal Comfort in Urban Space Renewal." Presented at International PLEA Conference, Geneva, Switzerland.

[15] ANSI/ASHRAE (American Society of Heating, Refrigerating and Air-Conditioning Engineers, Inc.). 2004. ANSI/ASHRAE (Standard 55-2004): Thermal Environmental Conditions for Human Occupancy. New York: ASHRAE. 
[16] Hoppe, P. 1999. "The Physiological Equivalent Temperature: A Universal Index for the Biometeorological Assessment of the Thermal Environment." International Journal of Biometeorology 43: 71-5.

[17] Fanger, P. O. 1970. Thermal Comfort. Copenhagen: Danish Technical Press.

[18] Gagge, A. P., Fobelets, A. P., and Berglund, L. G. A. 1986. "Standard Predictive Index of Human Response to the Thermal Environment." ASHRAE: Transactions 92: 709-31.

[19] Fiala, D., Havenith, G., Bröde, P., Kampmann, B., and Jendritzky, G. 2012. "UTCI-Multi-node Model of Human Temperature Regulation and Thermal Comfort." Int. J. Biometeorol. 56 (3): 429-41.

[20] Ameur, K. 1999. "Validation of a Thermal Comfort Index for Public Out Spaces.” Presented at V National Meeting of Comfort Built Environment and II Latin American Meeting on Comfort in the Built Environment, Fortaleza, Brazil.

[21] Martini, A., Biondi, D., Batista, A., Zamproni, K., Viezzer, J., Grise, M., et al. 2014. "Perception of the Population on the Thermal Comfort Provided by the Planting of Streets of Curitiba-PR." Floresta 44 (3): 515-24. (in Portuguese)

[22] Matzarakis, A., Muthers, S., and Ruthz, F. 2014. "Application and Comparison of UTCI and PET in Temperate Climate Conditions." Finisterra 49 (98): 21-31.

[23] Knez, I., Thorson, S., and Eliasson, I. 2009. "Psychological Mechanisms in Outdoor Place and Weather Assessment: Towards a Conceptual Model." In. J. Biometeorol 53: 101-11.

[24] Nikolopoulou, M., and Lykoudis, S. 2006. "Thermal Comfort in Outdoor Urban Spaces: Analysis Across Different European Countries." Elsevier: Building and Environment 41: 1455-70.

[25] Nikolopoulou, M., and Lykoudis, S. 2003. "Thermal Comfort in Outdoor Spaces: Field Studies in Greece." Presented at 5th International Conference on Urban Climate, Göteborg, Sweden.

[26] Nikolopoulou, M., and Lykoudis, S. 2007. "Use of Outdoors Spaces and Microclimate in a Mediterranean Urban Area." Elsevier: Building and Environment 42: 3691-707.

[27] Knez, I., and Thorson, S. 2008. "Thermal, Emotional and Perceptual Evaluations of a Park: Cross-Cultural and Environmental Attitude Comparisons." Building and Environment 43: 1483-90.

[28] Alcoforado, M., Andrade, H., Lopes, A., and Vasconcelos, J. 2009. "Application of Climatic Guidelines to Urban Planning: The Example of Lisbon
(Portugal)." Elsevier: Landscape and Urban Planning 90: 56-65.

[29] Oliveira, S., Andrade, H., and Vaz, T. 2011. "The Cooling Effect of Green Spaces as a Contribution to the Mitigation of Urban Heat: A Case Study in Lisbon." Elsevier: Building and Environment 46: 2186-94.

[30] Amirtham, L., Horrison, E., and Rajkumar, S. 2014. "Study on the Microclimatic Conditions and Thermal Comfort in a Institucional Campus in Hot Humid Climate." Presented at 30th International PLEA Conference, Anais, Ahmedabad, India.

[31] Gulyas, A., Unger, J., and Matzarakis, A. 2006. "Assessment of the Microclimatic and Human Comfort Conditions in Complex Urban Environment: Modellings and Measurements." Elsevier: Building and Environment 41: 1713-22.

[32] Cheng, V., Ng, E., Chan, C., and Givoni, B. 2010. "Outdoor Thermal Comfort in Sub-tropical Climate: A Longitudinal Study in Hong Kong." Presented at Conference: Adaptation Change: New Thinking Comfort, Cumberland Lodge, London, UK.

[33] Lin, T. 2009. "Thermal Perception, Adaptation and Attendance in a Public Square in Hot and Humid Regions." Elsevier: Building and Environment 44: 2017-26.

[34] Matzarakis, A., Rutz, F., and Mayer, H. 2007. "Modeling Radiation Fluxes in Simple and Complex Environments-Application of the Rayman Model." Inst. Biometeorol. 51: 323-34.

[35] Dacanal, C., Ribeiro, B., Rancura, R., and Labaki, L. 2009. "Thermal Comfort in Free Public Spaces: A Case Study in Campinas-SP." Presented at ENCAC (Encontro Nacional de Conforto no Ambiente Construdo e VI Encontro Latino-americano de Conforto no Ambiente Construdo), Natal, Brazil. (in Portuguese)

[36] Faustini, F. B., and Fontes, M. S. 2010. "Thermal Comfort in Public Spaces of Passage: Studies on the Boardwalk of Batista de Carvalho in Bauru-SP." Presented at 4th Luso Brazilian Conference on Urban, Regional, Integrated and Sustainable Planning (Pluris 2010), Lisbon, Portugal. (in Portuguese)

[37] Labaki, L., Fontes, M., Bueno-Bartholomei, C., and Dacanal, C. 2012. "Thermal Comfort in Public Spaces of Passage: Studies on Pedestrian Streets in the State of São Paulo in Brazil." Ambiente Construido 12 (1): 167-83. (in Portuguese)

[38] Mayer, H., and Hoppe, P. 1987. "Thermal Comfort of Man in Different Urban Environments." Theor. Appl. Climatol. 38: 43-9.

[39] Chirag, D., and Ramachandraiah, H. 2010. "The Significance of Physiological Equivalent Temperature (PET) in Outdoor Thermal Comfort Studies." 
International Journal of Engineering Science and Technology 2 (7): 2825-8.

[40] Matzarakis, A., and Amelung, B. 2008. "Physiological Equivalent Temperature as for Impacts of Climate Change on Thermal Comfort of Human." In Seasonal Forecasts, Climatic Change and Human Health, edited by Thomson, M. C. Dordrecht: Springer Science + Business Media B.V.

[41] Matzarakis, A., Rutz, F., and Mayer, H. 2000. "Estimation and Calculation of the Mean Radiant Temperature within Urban Structures." In Biometeorology and Urban Climatology at the Turn of the Millenium, edited by De Dear, R. J., Kalma, J. D., Oke, T. R., and Auliciems, A. In Proceedings of the Conference ICB-ICUC'99, WCASP-50, WMO/TD No. 1026, 273-8.

[42] Monteiro, L. M., and Alucci, M. P. 2007. "Thermal Comfort in Open Spaces with Different Microclimate Factors: Part 2: Proposal of Predictive Models Calibration." In Proceedings of National Meeting ANTAC -9th Latin American Meeting of Comfort in the Built Environment, 1231-40. (in Portuguese)

[43] ISO (International Standard Organization). 1998. International Standard-ISO 7726/1998-Ergonomics of the Thermal Environment-Instruments for Measuring Physical Quantities. Geneva: ISO.

[44] Giridharan, R., Lau, S., Ganesan, S., and Givoni, B. 2008. "Lowering the Outdoor Temperature in High-Rise High-Density Residential Developments of Coastal Hong-Kong: The Vegetation Influence." Elsevier: Building and Environment 43: 1583-95.

[45] Oke, T. 1988. "Street Design and Urban Canopy Layer Climate." Elsevier: Energy and Buildings 11: 103-13.

[46] Shashua-Bar, L., Tsiros, I., and Hoffman, M. 2010. "A Modeling Study for Evaluating Passive Cooling Scenarios in Urban Streets with Trees-Case Study: Athens, Greece." Elsevier: Building and Environment 45: 2798-807.
[47] Abreu, L., and Labaki, L. 2010. "Thermal Comfort Afforded by Some Tree Species: Evaluation of the Radius of Influence through Different Levels of Comfort." Ambiente Construído 10 (4): 103-17. (in Portuguese)

[48] Anjos, M., Gois, D., Cruz, R., and Lima, L. 2012. Urban Climatology and Open Spaces: Contribution to the Planning of the Cities." Geonorte Magazine (Special Edition) 2 (5): 233-45. (in Portuguese)

[49] Giridharan, R., Lau, S., Ganesan, S., and Givoni, B. 2007. "Urban Design Factors Influencing Heat Island Intensity in High-Rise High-Density Environments of Hong-Kong." Elsevier: Building and Environment 42: 3669-84.

[50] Shashua-Bar, L., Pearlmutter, D., and Erell, E. 2009. "The Cooling Efficiently of Urban Landscape Strategies in a Hot Dry Climate." Elsevier: Landscape and Urban Planning 92: 179-86.

[51] Eliasson, I., and Svesson, M. K. 2003. "Spatial Air Temperature Variations and Urban Land Use a Statistical Approach." Meteorol. Appl. 10: 135-49.

[52] Givoni, B., Noguchi, M., Saaroni, H., Poechter, O., Yaacov, Y., Feller, N., et al. 2003. "Outdoor Comfort Research Issues." Elsevier: Energy and Buildings 35: 77-86.

[53] Katzschner, L., Bosch, U., and Rotten, M. 2003. "A Methology for Bioclimatic Microscale Mapping of Open Spaces." Presented at 5th ICUC (International Conference on Urban Climate), Lodz, Poland.

[54] Matueschek, O., and Matzarakis, A. 2010. "Estimation of Sky View Factor in Complex Environment as a Tool for Applied Climatological Studies." Presented 7th Conference on Biometeorology, Freiburg, Germany.

[55] Preiser, W., and Vischer, J. 2005. Assessing Building Performance. Oxford: Elsevier.

[56] Zeisel, J. 1995. Inquiry by Design: Tolls for Environment-Behavior Research. Cambridge: Cambridge Univ. Press. 